\title{
Prospective Teachers' Views on Courses for Culturally Responsive Pedagogy
}

\author{
Nurfaradilla Mohamad Nasri, Asyraf Talib, Bity Salwana Alias
}

\begin{abstract}
While there is a growing body of researches on culturally responsive curriculum, nonetheless, the efficacy of culturally responsive curriculum courses for prospective teacher in preparing these soon-to-be teachers to teach culturally responsive have not been examined thoroughly especially from the perspectives of these teachers. This study was undertaken to fill these gaps and to improve understandings of culturally responsive curriculum. Furthermore, it is hoped that the outcomes of this study could potentially help teacher training programs to understand their effectiveness in training teachers for implementing culturally responsive pedagogy and further improve their programs.

Keywords : Culturally Responsive Pedagogy, Prospective Teachers, Culture, Courses
\end{abstract}

\section{CONCEPT OF CULTURE}

Understanding the concepts of culture is very important for all educators, to recognise the reasons why educators are encouraged to develop and implement instruction that was more in tune with students' cultural background and students' everyday lives experiences. The word 'culture' embraces a plethora of concepts, which are interpreted in many different ways and are used to describe many different things. Broadly, culture can be viewed as a collection of information (or meanings) that is (a) nongenetically transmitted between individuals, (b) more or less shared within a population of individuals, and (c) maintained across some generations over a period of time (Gay, 2013). From a historical perspective, culture is seen as a heritage passing on through the generations (Jabbar \& Hardaker, 2012) while from a psychological perspective, culture is seen as a problem solving device that helps people communicate, learn or show emotional needs (Chakkarath, 2017). From a different point of view, Hofstede et al (2010) proposes that cultures can be categorised into five dimensions:

a. Power distance: extent to which the less powerful members of communities and institutions expect and accept that power is distributed unequally;

b. Collectivism versus individualism: collectivism refers to a society that emphasis strong in-groups ties, while individualism implies a society in which everyone is expected to look after themselves and their immediate family only;

c. Femininity versus masculinity: femininity refers to society that focused on the quality of life. Masculinity implies a society that focuses on

Revised Manuscript Received on July 22, 2019.

Nurfaradilla Mohamad Nasri, Asyraf Talib, Bity Salwana Alias, College of science for women-Chemistry Department/ University of Babylon -Iraq, Almustaqbal University College, HILLA, IRAQ material success, competition and being tough

d. Uncertainty avoidance: extent to which the members of community feel threatened and uncomfortable by ambiguous and unknown situations; and

e. Long-term orientation versus short-term orientation: long-term orientation is the extent to which members of a society adapt themselves to meet a desirable future. On the other hand, short-term orientation is the extent to which numbers of a society try to fulfil their present needs and desires.

Hofstede's cultural dimensions contribute to understanding the learning and teaching orientations practiced in classroom in different cultures. For example, in a society with a large power distance, teachers are regarded as the main player of the classroom and are held responsible to initiate all communication in class. While students are usually described as passive recipients that favour group works. Vice versa, the education in a society with a small power distance is usually student-centred where teachers and students are considered equals. Additionally, a society with strong uncertainty avoidance, students want to know the right answer, but in a society of weak uncertainty avoidance, students want discussions (Hofstede, 1997). In high-context culture or collectivistic culture, the silence or non-verbal expressions are common communicative behaviour which is regarded as a sign of respect to their teachers. In the context of classrooms, students from this culture are expected to listen to their teacher and only talk when the teacher asks a question (Truong, Hallinger \& Sanga, 2017).

It is clear that the response a student has to a learning activity is greatly influenced by his or her culture and students' learning styles varies distinctively from culture to culture. It is noted that teaching which ignores students' culture norms may provokes student resistance (Gay, 2013). Therefore, establishing sensitivity towards students' cultural orientation is important to create a feeling of inclusion and connection which may motivate students to deeply engage in learning activities (Wlodkowski, 2008; Banks, 2008; Kumar, Zusho \& Bondie, 2018). In this instance, failing to acknowledge and understand the students' culture and behaviours towards learning might result in misconceptions about their motivation to learn and intellectual abilities (Sulkowski \& Deakin, 2009; Gay, 2013).

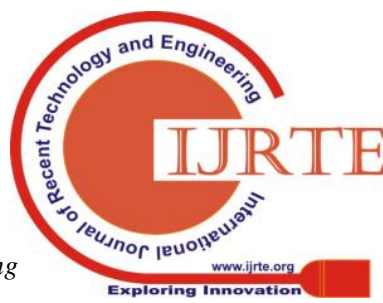


Although culture is often thought of in terms of ethnic, race or national groups, some of the researchers suggested that cultures can also be looked, within or beyond ethnic groups, in terms of race, gender, or even socio-economic class. A point to note, even though Hofstede's cultural dimension serves as one of the key reference for this study which seeks to investigate the role of culture in teaching and learning, the cultural concepts used in this study are not limited to people's value, norms and behaviour as suggested by the historical and psychological perspectives. Another aspect of culture that plays a role in education is to coalesce students' culture to be more than mere national origin or race (Gay, 2013, 2015). In respect to these values, cultures in the sense used here is multidimensional and dynamic, and influence by many factors such as students' outside learning experiences (Funds of Knowledge) (Moll, Amanti, Neff \& Gonzalez, 1992; Mohd Norawi, Halim, Osman, 2015) and cultural objects which greatly reflect Gay's (2015) broad and innovative view of culture.

\section{CHARACTERISTICS OF CULTURALLY RESPONSIVE PEDAGOGY}

Culturally responsive pedagogy (CRP) is essential for all and it is important particularly for teaching a heterogeneous classroom (Gay, 2015). Teachers that practices CRP frame their pedagogical values around students' diverse funds of knowledge and strives to best serve their students' learning needs by connecting in-school learning to out-of-school living. According to Fullan, Quinn \& McEachen (2018) this continuity is critical in engaging students for meaningful learning. Ladson-Billings (1995) describes culturally relevant pedagogy as a pedagogy that address individual culture. Similarly Gay (2010) defined CRP as teaching strategies that uses students' cultural knowledge and prior experiences to make learning encounters relevant to their lives. Most importantly Gay (2010) asserted that CRP teaches to and through the strengths of the students.

Hollins (1993) who reviewed four seminal studies suggested seven characteristics of CRP: (a) communicate effectively with diverse learners, (b) mastering the subject content knowledge and students as unique individual, (c) reflective teachers, (d) using various learning resources, (e) offering supportive learning environment, (f) developing interpersonal relationships, and $(\mathrm{g})$ promoting learner performance. Expanding Hollins (1993) list of CRP characteristics, Gay (2010) suggested 14 specific competencies for CRP which includes:

a) communicating high expectations;

b) actively engage students in learning;

c) facilitating learning activity;

d) recognizing students' prior knowledge and experiences;

e) anchoring curriculum in the students' everyday lives;

f) ensuring teaching activity meets students' learning needs; g) sharing class control with students;

h) engaging in reflective thinking;

i) visiting students' families and communities

j) exploring students personal and family histories

k) celebrating and appreciating diversity

1) acknowledging membership in different groups

$\mathrm{m})$ learning the history and experiencing of diverse groups and:

n) actively participate in reforming the institution

Based on these literatures, it is evident that the primary tenet of CRP revolves around

teaching practices that uses students' local cultural background as a focal point in designing learning activity. A point to note, culturally responsive pedagogy is originally offered as a call to activate plans for equity in education. Since its introduction, CR has been coined by many researches as one of the key components that not only improve students' academic performance but also empowers them to direct their own lives and improved the lives of others. Agreeing with other researchers on the potential of CRP to promote equity in education by narrowing the academic achievement gap, this study urges for urgent need in preparing teachers with CRP competencies especially in Malaysian context where its people consist of multicultural and diverse background.

\section{COURSES OFFERED ON TEACHERS' PREPARATION: CULTURALLY RESPONSIVE PEDAGOGY}

There is a wide body of literature on teacher preparation program which focuses on developing prospective teachers' skillsets and capacities for teaching effectively in a classroom. According to Yuan (2017), in order to nurture prospective teachers' positive teaching attitudes towards the diversity of their students and fostering skills in CRP, a teacher training is needed for these prospective teachers. The idea that teachers and college faculties need to receive particular preparation and knowledge structure in order to work efficiently with diverse student populations has been a part of professional discourse for a long time (Goodwin 1997). Nations from all over the world have been integrating courses that would prepare its teachers to teach a classroom filled with diverse students. In the United States of America, the diversity of its students in the public schools has risen in recent years. The rise in the percentage has resulted in teachers in America to prepare themselves a new teaching approach in their classroom. Teachers are being challenged by researchers to contemplate on how to incorporate CRP into their education programs to support pre-service and prospective teachers (Boyd \& Noblit, 2015; Brown-Jeffy \& Cooper, 2011; Durden, Dooley, \& Truscott, 2016; Dyches \& Boyd, 2017; Howard, 2003; Jimenez, 2014; Ladson-Billings, 2014; Picower \& Kohli, 2017; Tschida, Ryan, \& Ticknor, 2014; Zygmunt, Clark, Clausen, Mucherah, \& Tancock, 2016). Among the wide range of activities included for pre-service teachers in their teacher education

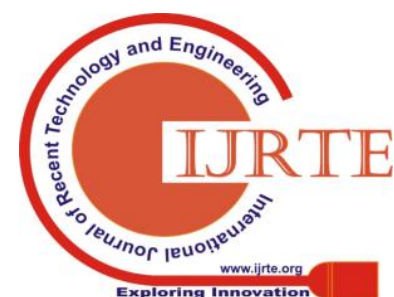


program was to experience a direct interaction with people of diverse background in a cross-cultural field experiences (Leland \& Harste, 2005). For instance, Nieto (2006) in his study stated that direct interaction with people of different background and culture boosted the cultural understanding of the pre-service teachers, which in return helped them develop positive outlooks towards minorities, and reduced their fear of these students and their communities. Gay and Kirkland (2003) define ways to accomplish this outcome, such as stimulating critical self-reflection, keeping teachers accountable for student achievement, and let teachers "think (...) deeply and analytically" (p. 181). This is argued by Ladson-Billings (2000) where he believes that courses where pre-service teachers write autobiographies, participate in field-experiences, experience situated pedagogies, or observe in expert classrooms can contribute to prepare them for diverse classrooms. Teachers in America are also being encourage to take the initiative of learning and diving into the culture of their multicultural students. This is to ensure their readiness in providing the suitable content for their lessons.

Efforts have been done in Asian countries who are facing the same situation as its Western neighbours. According to Indonesia's National Education System, it is clearly stated that "education must be democratic, non-discrimination and promote human rights, religious

values, cultural values and national diversity" (s. 20). This shows that the Indonesian government are putting an effort in implementing CRP in their education system. Indonesian teachers are expected to conduct their lesson with content that are suitable of its diverse students. This is to get the students feel connected with the lesson without feeling isolated or unfamiliar with the lesson. Brown-Jeffy and Cooper (2011) in their article highlighted that a teacher with a different cultural background that its students could result in a gap in the teaching and learning process between the teacher and the students. Results of these researches has created a catalyst from the government to provide a CRP course for prospective teachers in Indonesia.

In Malaysia, the government has been implementing and formulating a number of policies to unite and harmonize its people with different background, culture, and ethnic by using education as a vessel to achieve its goals (Malakolunthu, 2010). Many pre-service teachers are introduced to courses that touch on CRP during their teacher training programs. For most of the teachers, these courses were usually offered during their undergraduate or graduate program and the multicultural education concepts were merely created as a supplement to education rather than integrating it in the curriculum and instruction (Yusof, 2008). Yusof (2008) then added that although the courses are on a superficial level, it creates an awareness for the teachers to "become acquainted with multicultural education concepts and practices through a variety of avenues based on their own interests and levels of motivation or the insights and incentives of their school and district administrators." Teachers in Malaysia are actively seeking for courses or seminars that will provide them the components in CRP.
This is due to the fact that cultural diversity was not considered as a concrete educational issue when these teachers started their teaching profession (Yusof, 2008). As the years progressed, many initiatives are taken to provide prospective teachers the proper CRP training to ensure the practice of CRP in the classroom among the schools in Malaysia.

\section{RESEARCH DESIGN}

This study used qualitative research method to acquire a deeper understanding of human behaviour, belief system, attitudes, emotions and their experiences. A focus group discussion with 20 postgraduate students with diverse educational background was conducted for over an hour. Among the 20 students, 16 of them were consist of female while 4 were male students. Some of the students have been working for over 5 years in the education field both in the government and private sectors specializing in Teaching English as Second Language.

Two primary research questions were the focus of this study. They were:

1) How did pre-service teachers perceive the courses on CRP that they enrolled during their teacher preparation program?

2) How did these courses prepare them to design CRP practices?

During the focus group discussion, we took notes to reflect insights from each research participants' story and recorded the session to enable us to listen back to the recordings should we require to during the transcribe process. Afterwards, we gave the transcripts to all of the research participants to ensure that the focus group discussion session was accurately portrayed. They were also encouraged to edit or omit any parts that inaccurately represented their beliefs of perspectives. Following a hybrid approach of analysing interview data, three themes emerged as worthy mention which are:

1) Greater depth of insights about CRP is needed,

2) Increased self-consciousness about CRP influence their preferred teaching practices,

3) A lack of consistency in what CRP means and how it is enacted

Theme 1: Greater depth of insights about CRP is needed

Almost all of the research participants reported that their bachelor degree programs did not prepare them for better understanding of CRP. Most of the topics that were taught in the courses that were supposed to highlight CRP were only superficial and focused on the diversity of the students' learning styles and cognitive physical ability rather than their culture. It is relatively rare for these courses to explain in details on the origins of the CRP concept and its purposes in education. Nevertheless, the needs for teachers to develop an awareness of the students' culture is often emphasized. However, these courses do not 
go into great details of how this CRP can be implemented. Thus, the research participants informed that they tend to implement CRP based on individual understanding of culturally responsive classroom. The proper guideline is needed for the teachers to be able to implement CRP in their classroom, as suggested by one of the research participant. Most of the participants agreed that pre-service teachers should be provided with a CRP course to delve deeper into their role in implementing CRP and the importance of CRP in the education system.

Theme 2: Increased Self-consciousness about CRP influence their preferred teaching practices

Research participants reported that being self-conscious about one's self-identity and culture highly influence their perspective on CRP. This is supported by one of the research participants who is Chinese and went to a national school where the majority of its students were Malays. Due to this situation, the research participant had to blend in and assimilate to the dominant culture in order to survive. The experience became a major turning point in her life in which she has become more sensitive towards her students especially her minority students. She then added that during her practical days, she used various teaching approaches and referred to numerous sources and references in order to keep her teaching context relevant for her diverse students. Nevertheless, a lingering feeling of regret resides in her because of the lack of proper exposure she received during her teacher training on this matter. This resulted her in becoming unprepared and less confident during her teaching sessions.

The same can be said by another research participants who is currently teaching in one of a national school with students from SJKC transferring to his school. The research participant continued by saying that some of the SJKC students were transferred to his class and he had quite a difficult time trying to readjust the content of his lessons to accommodate the new students. Most of the time, he had to refer to his Chinese students to translate to the SJKC students on what he is trying to tell them or what they are telling him. He confessed that it took a toll on the quality of his teachings due to the extra time and attention needed for these students. During the early stages, he had no idea what to do since he did not received a proper training on CRP. Nevertheless, the occurrence of this has increased his self-consciousness about $\mathrm{CRP}$ and its influence in his teaching practices. It is unfortunate for him that he never got the opportunity to properly learn in details on CRP.

Theme 3: A lack of consistency in what CRP means and how it is enacted

Supposedly by learning CRP courses, the individual should have a better grasp on CRP, its impact on teaching and learning and teaching strategies that promotes culturally responsive classroom environment. Nonetheless, since CRP is centred on certain fundamental concepts, various definitions of CRP have been introduced in CRP courses at the bachelor level to enhance their understanding of CRP. However, despite various definitions of CRP offered by researches, CRP has created some confusion among them. Majority of them are unsure of the differences between contextual learning, situated learning, and experiential learning. What worries most is that they believe that all four of the concepts are similar and they tend to use these concepts interchangeably. Due to their lack of understanding on the foundation of CRP, the teaching methods that they have chosen do not reflect the actual CRP approach. Teaching evaluation during the training session at the bachelor level also do not assess their ability to conduct CRP. As a result, the needs to implement CRP are considered as insignificant and unimportant.

This contradicts when it comes to the real classroom situations. Two of the research participants stated that they had to discover the concept of CRP on their own without being given a proper training on it. They added that most of the teachers conducted their CRP lesson based on what they understood of CRP. Thus, this creates confusion among the teachers without a proper source that they could refer to. According to them, not even the senior teachers are familiar with CRP since they themselves were not properly exposed to its content.

\section{DISCUSSION AND CONCLUSION}

Although a great number of theorist and practitioners of CRP has acknowledge the potential of CRP to promote equity in education, there is a lack of research references in the approach of a CRP particularly in Malaysia. This study focused on exploring prospective teachers' perspective of, and practices in implementing CRP. A study of this nature could provide indicators to teacher educators at higher education institution on various expects of improvement, particularly in producing CR teachers. Results of this study indicate that all of the research participants have their personal interpretation of CRP which causes diverse pedagogical strategies adopted. Furthermore, it sends a signal that teacher training courses that they attended failed to address they key aspects of CRP.

\section{REFERENCES}

1. Banks, J. (2008). An introduction to multicultural education (4th ed.) Boston: Pearson Education

2. Boyd, A. S., \& Noblit, G. W. (2015). Engaging students in autobiographical critique as a social justice tool: Narratives of deconstructing and reconstructing meritocracy and privilege with preservice teachers. Educational Studies, 51(6), 441-459.

3. Brown-Jeffy, S., \& Cooper, J. E. (2011). Toward a conceptual framework of culturally relevant pedagogy: An overview of the conceptual and theoretical literature. Teacher Education Quarterly, 38(1), 65-84

4. Chakkarath, Pradeep. (2017). A Cultural Psychological View on Human Culture and Cultural Development. Evolutionary Studies in Imaginative Culture. 1. 43-46. 10.26613/esic/1.1.6.

5. Durden, T., Dooley, C. M., \& Truscott, D. (2016). Race still matters: Preparing culturally relevant teachers. Race

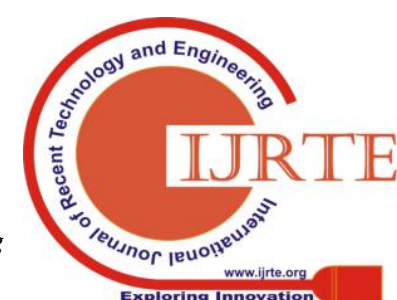


Ethnicity and Education, 19(5), 1003-1024.

6. Dyches, J., \& Boyd, A. (2017). Foregrounding equity in teacher education: Toward a model of socialjustice pedagogical and content knowledge. Journal of Teacher Education, 68(5), 476-490.

7. Fullan, M., McEachen, J., \& Quinn, J. (2018). New Pedagogies for Deep Learning 2018 NPDL Global Report. Ontario, Canada: Retrieved from: http://npdl.global/wp-content/uploads/2018/05/NPDL-Global-Report-201 8.pd

8. Gay, G. (2015), "The what, why, and how of culturally responsive teaching: international mandates, challenges, and opportunities", Multicultural Education Review, Vol. 7 No. 3, pp. 123-139.

9. Gay, G. (2013). Teaching to and through cultural diversity. Curriculum Inquiry, 43(1), 48-70.

10. Gay, G. (2010). Culturally responsive teaching: Theory, research, and practice. New York, NY:Teachers College Press.

11. Gay, G., \& Kirkland, K. (2003). Developing cultural critical consciousness and self-reflection in preservice teacher education. Theory into Practice, $42(3), 1-8$

12. Goodwin, A. L. (1997). Historical and contemporary perspectives on multicultural teacher education.In J. King, E. Hollins, \& W. Hayman (Eds.), Preparing teachers for cultural diversity (pp. 5-22). New York: Teachers College Press

13. Hofstede, G., Hofstede, G. J. \& Minkov, M. (2010). Cultures and Organizations: Software of the Mind (Rev. 3 rd ed.). New York: McGraw-Hill

14. Hofstede, G. (1997) Cultures and Organizations: Software of the Mind, London: McGraw-Hill.

15. Hollins, E. R. (1993). Assessing teacher competence for diverse populations. Theory into Practice, 32,93-99.

16. Howard, T. C. (2003). Culturally relevant pedagogy: Ingredients for critical teacher reflection. Theory into Practice, 42(3), 195-202.

17. Jabbar, A. and G. Hardaker (2012). "The role of culturally responsive teaching for supporting ethnic diversity in British University Business Schools." Teaching in Higher Education: 1-13

18. Jimenez, L. M. (2014). "So like, what now?": Making identity visible for preservice teachers. Journal of Language and Literacy Education, 10(2), 69-86

19. Kumar, R., Zusho, A., \& Bondie, R. (2018). Weaving cultural relevance and achievement motivation into inclusive classroom cultures. Educational Psychologist, 53(2), 78-96.

20. Ladson-Billings, G. (2014). Culturally relevant pedagogy 2.0: A.k.a the remix. Harvard Educational Review, 84(1), 74-84

21. Ladson-Billings, G. (2000). Racialized discourses and ethnic epistemologies. In N. K. Denzin \& Y. S. Lincoln (Eds.), Handbook of qualitative research (2nd ed., pp. 257-277). Thousands Oaks, CA: Sage.

22. Ladson-Billings, G. (1995). Toward a theory of cultural relevant pedagogy. American Educational Research Journal, 32, 465-491.

23. Leland, C. \& Harste, J. (2005). Doing what we want to become: Preparing new urban teachers. Urban Education, 40(1), 60-77

24. Malakolunthu, S. (2000). Culturally responsive leadership for multicultural education: The case of "Vision School" in Malaysia. Procedia - Social and Behavioral Sciences, 9, 1162-1169.http://dx.doi.org/10.1016/j.sbspro.2010.12.301

25. Moll, L. C., Amanti, C., Neff, D., \& Gonzalez, N. (1992). Funds of knowledge for teaching:Using a qualitative approach to connect homes and classrooms. Theory into Practice, 31, 132-141

26. National Education System 2003 [Sistem Pendidikan Nasional Tahun 2003](Jkt)

Retrievedfrom https://kemenag.go.id/file/dokumen/UU2003.pdf

27. Nieto, J. (2006). The cultural plunge: Cultural immersion as a means of promoting selfawareness andcultural sensitivity among student teachers. Teacher Education Quarterly, 33(1), 75-84.

28. Norawi Ali, Mohd \& Halim, Lilia \& Osman, Kamisah. (2015). Integration of Funds ofKnowledge as Contextual Knowledge. Research Journal of Applied Sciences, Engineering and Technology. 10. 129-137.

29. Picower, B., \& Kohli, R. (Eds.). (2017). Confronting racism in teacher education: Counternarratives ofcritical practice. London, UK: Taylor \& Francis.

30. Sulkowski, N. B. and Deakin, M. K. (2009) Does Understanding Culture Help EnhanceStudents' Learning Experience?, International Journal of Contemporary HospitalityManagement, 21 (2): 154-166

31. Thang, Truong \& Hallinger, Philip \& Sanga, Kabini. (2016). Confucian Values and SchoolLeadership in Vietnam: Exploring the Influence of Culture on Principal Decision Making. Educational Management Administration \& Leadership. 45.10.1177/1741143215607877

32. Tschida, C., Ryan, C., \& Ticknor, A. S. (2014). Building on windows and mirrors: Encouraging thedisruption of Single Stories" through children's literature. Journal of Children's Literature,40(1), 28-39.

33. Wlodkowski, R. J. (2008). Enhancing Adult Motivation to Learn: A Comprehensive Guide forTeaching All Adults (3rd ed.). San Francisco: Jossey-Bass. 528 pp
34. Yuan, H. (2017). Developing Culturally Responsive Teachers: Current Issues and a Proposal forChange in Teacher Education Programs. World Journal of Education, 7(5), 66.

35. Yusof, Najeemah (2008). "Multicultural education: managing diversity in Malaysian schools".Malaysian Education Deans Council Journal, Vol.2

36. Zygmunt, E., Clark, P., Clausen, J., Mucherah, W., \& Tancock, S. (2016). Transformingteacher education for social justice. New York, NY: Teachers College Press. 